\title{
Changes in Lower Limb Muscle Activity during Lunge according to the Different Angle of Ankle Joint
}

\author{
Heun-Jae Ryu, Youn-Tae Kim, Hee-Joon Park, Jung-Won Kwon \\ Department of Physical Therapy, College of Health Sciences, Dankook University, Cheonan, Republic of Korea
}

Purpose: This study compared the muscle activity of the lower limb according to the three types of fixed angles of the ankle joint during a lunge exercise.

Methods: Twenty healthy subjects performed the lunge motion in a trial including the three types of fixed angle. The lunge motion with a neutral, $20^{\circ}$ dorsiflexion, and $20^{\circ}$ plantarflexion of the ankle joint were randomized and measured repeatedly. The muscle activity of the rectus femoris (RF), vastus medialis (VM), vastus lateralis (VL), biceps femoris (BF), and semitendinosus (ST) was measured by surface electromyography.

Results: In the change in ankle joint angle, the $\mathrm{RF}, \mathrm{VL}, \mathrm{BF}$, and $\mathrm{ST}$ muscle activity showed significant differences $(\mathrm{p}<0.05)$. In the $20^{\circ}$ dorsiflexion position, the muscle activity of $\mathrm{VL}, \mathrm{BF}$, and ST showed a significant decrease compared to that in the neutral position $(p<0.017)$. The muscle activity of RF and VL in the neutral position was greater than that in the $20^{\circ}$ plantarflexion position $(p<0.017)$. Only the muscle activity of the $\mathrm{BF}$ in the $20^{\circ}$ plantarflexion position was significantly greater than the $20^{\circ}$ dorsiflexion position $(\mathrm{p}<0.017)$.

Conclusion: These results revealed a difference in the muscle activity of lower extremities in the proximal region according to the angle of the ankle joint during the lunge.

Keywords: Ankle joint, Electromyography, Lunge, Quadriceps muscle, Hamstring muscle

\section{서 론}

대표적인 하지의 닫힌사슬 운동 중 하나인 런지(lunge) 운동은 스쿼 트(squat), 스텝업(step-up), 케틀벨스윙(kettlebell swing) 등과 같은 운 동에 비해 무릎 주변부 근육의 높은 근활성도를 보이는 특징을 가지 고 있다. 선행연구에 따르면 스쿼트, 런지, 케틀벨스윙 중 런지에서 넙 다리곧은근이 가장 높은 근활성도를 보였으며,' 런지 운동은 가쪽넓 은근과 안쪽넓은근의 근활성도를 높여 재활 초기 하지의 가쪽넓은 근과 안쪽넓은근의 균형조절에 효과적인 운동으로 알려져 있다., ${ }^{2,}$ 특 히 Ekstrom 등은 런지 운동이 스쿼트에 비해 안쪽넓은근의 선택적 인 강화에 더 효과적이라고 하였으며, Park 등은 젊은 여성을 대상으 로 12 주 동안 런지 운동을 시행하였을 때 동적인 동작수행능력과 하 지 폄근의 근력 향상에 도움을 준다고 보고하였다. 이러한 런지 운동 은 하지의 대항근이 서로 편심성으로 작용함으로써 손상된 관절의 동적인 안정성에 많은 영향을 주어 임상에서 많이 활용되고 있다.

임상적으로 무릎넙다리 통증 증후군(Patellofemoral pain syndrome)

Received Jan 12, 2021 Revised Feb 03, 2021

Accepted Feb 04, 2021

Corresponding author Jung-Won Kwon

E-mail kjwonpt@hanmail.net
및 앞십자인대 수술 이후 재활에서는 체중지지 운동인 닫힌사슬 운 동이 필수적인 요소로 포함되어 있다. 하지의 닫힌사슬 운동은 넙다 리네갈래근을 강화시키고, 동시에 가쪽넓은근에 비해 약한 안쪽넓 은근의 근력 불균형을 개선하기 위한 운동방법으로 ${ }^{5,6} \mathrm{Ekstrom}$ 등의 연구에서는 9 가지 재활운동(측면 교각 운동, 한발 교각 운동, 가쪽 스 텝업, 네발기기 자세-팔 다리 교차 들기, 능동적 엉덩관절 모음 운동, 다운힐 스키 운동, 런지, 교각 운동 그리고 플랭크) 중에서 다른 동작 들과 비교하여 런지가 안쪽넓은근의 근활성도가 가장 높게 나오는 특징을 가지고 있다. 이러한 임상 증상들을 개선하고 과도한 부하로 인한 손상을 예방하기 위해서는 런지와 같은 닫힌사슬 운동을 통한 하지 근육의 근력강화 운동이 필수적이다.

최근 하지 근육의 근력강화 운동을 할 때 하지의 근활성도를 극대 화하기 위한 다양한 운동형상학적 특성이 반영된 방법들이 적용되 고 있다. 예를 들어, 스쿼트 운동에서 발목각도의 변화에 따라 내려 갈 때, 유지할 때 그리고 올라갈 때의 3 가지 구간에서 하지의 가쪽넓 은근과 안쪽넒은근의 근활성도에서 차이가 나타났으며, $10^{\circ}$ 발등굽 
힘 상태에서는 안쪽넓은근의 근활성도가 올라갈 때 선택적으로 높 았고, $10^{\circ}$ 발바닥굽힘 상태에서 안쪽넓은근과 가쪽넓은근의 근활성 도는 유지할 때와 올라갈 때 모두 높게 나타났다. 또한, 런지 운동을 수행할 때 발 위치와 간격의 차이에 따라 안쪽넓은근과 넙다리곧은 근의 근활성도에 차이가 나타났으며, ${ }^{8}$ 발목관절의 모음, 벌림, 중립 위 치에 따라 넙다리네갈래근의 근활성도에 다른 양상이 나타난다고 하였다. 하지 근육의 근력강화 운동 시 지지면의 상태도 근활성도에 많은 영향을 주며, 특히 불안정한 지지면에서 스쿼트 운동을 할 때 가 자미근과 몸통의 안정화 근육의 근활성도가 높아지고 런지 운동을 할 때에도 안쪽넓은근 근육에서 근활성도가 높았다.10,11 따라서 스쿼 트 운동이나 런지 운동과 같은 하지의 근력강화 운동은 환경, 장소그 리고 시간의 제한이 없고 간단하게 수행할 수 있지만 발목관절의 각 도와 무릎관절의 각도 혹은 발의 위치와 지지면의 상태 등에 따라서 하지 근활성도에 차이가 있기 때문에 임상에서 여러 변수들을 변화 시켜 적용할수 있다. ${ }^{12}$

이와 같이 하지의 닫힌사슬 운동의 근활성도를 극대화하기 위한 발목관절의 각도 및 발 위치의 변화에 따른 하지의 근활성도 차이에 대한 연구가 보고되었다. ${ }^{13}$ 런지에 관한 선행 연구에서도 발의 앞, 뒤 간격의 차이로 하지의 근활성도의 비교에 따른 차이를 보여주었고, ${ }^{8}$ 이는 런지 운동 시 앞발을 앞으로 뻗는 길이에 따라 발목관절의 각도 가 변화될 수 있다. 기존 선행연구에서는 발의 위치로 근활성도의 차 이를 연구한 것에 비해 본 연구는 순수한 발목 각도에 따른 하지의 근활성도에 차이가 있으며, 발판을 이용하는 것과 같이 지지면의 기 울기에 따라 런지 운동을 할 때에도 하지의 근활성도 차이가 있을 것 으로 가정하였다. 따라서 본 연구에서는 건강한 성인을 대상으로 발 목관절의 각도에 따른 런지 운동 시 하지 근육의 근활성도의 차이를 비교하여 근력강화에 가장 효과적인 런지 운동을 제시하고자 한다.

\section{연구 방법}

\section{1. 연구대상}

본 연구의 대상자는 건강한 20 대의 성인 남녀 20 명을 무작위로 선정 하였다. 대상자의 선정 기준은 1) 런지 운동을 충분히 수행할 수 있는 자, 2) 능동 관절가동범위 검사에서 발목관절의 정상적인 가동범위 인 발등굽힘 $20^{\circ}$, 발바닥굽힘 $50^{\circ}$ 이고 무릎관절에서 $0-135^{\circ}$ 범위를 가 진 자, 3) 하지 근육이나 관절에 근골격계 질환이나 수술 이력이 없는 자, 4) 신경학적 손상이 없는 자로 하였다. ${ }^{14}$ 또한, 최근 6 개월간 근력강 화 운동을 실시한 자와 현재 치료 중이거나 약물을 복용하고 있는 자는 제외하였다. 모든 대상자들에게 실험에 대한 이해를 돕기 위한 충분한 설명을 하였으며, 이를 바탕으로 대상자들의 자발적인 동의 를 얻어 연구를 시행하였다.

\section{2. 실험방법}

1) 측정도구

(1) 런지 운동 간격

런지 운동 시 대상자의 신체적 특성을 고려하여 동일한 발의 위치를 만들고 앞발과 뒷발의 간격을 정량화하기 위하여 실제 다리 길이를 측정하여 런지 운동 간격을 설정하였다. 실제 다리 길이는 침대에 바 로 누운 자세로 대상자를 눕게 하여, 대상자의 좌, 우 위앞엉덩뼈가시 를 수평으로 맞춘 뒤, 측정하고자 하는 다리의 위앞엉덩뼈가시의 가 장 튀어난 부분, 무릎관절 사이의 중심, 그리고 발목관절 상의 중심 을 일직선으로 한 상태에서 측정하였다. 측정은 숙련된 측정자가 양 쪽 다리 각각 3 회, 총 6 회를 측정하여 좌, 우 실제 다리길이의 평균값 을 사용하였다. 본 연구는 선행연구에서 제시된 기준에 따라 실제 다 리길이의 $40 \%$ 의 간격으로 앞발과 뒷발을 위치시켜 런지 운동을 수행 하도록 하였다. ${ }^{8}$

\section{(2) 근전도 검사(Electromyography)}

모든 대상자들은 반바지를 착용한 상태에서 근전도를 측정하였고, 런지 운동 시 넙다리곧은근, 가쪽넓은근, 안쪽넓은근, 넙다리두갈래 근, 반힘줄근의 활성도를 측정하기 위하여 표면 근전도 측정장비 (NORAXON Myosystem EMG, Noraxon Inc., USA)를 사용하였다. 전 극은 2 극으로 이루어진 표면 전극을 사용하였으며 이는 무선 송신기 와 연결되고 송신기가 무선으로 주파수를 수신기로 전송하여 데이 터를 수집하였다. 근전도 신호의 주파수 대역폭은 $40-250 \mathrm{~Hz}$ 로 설정 하였고 샘플링 주파수는 $1,000 \mathrm{~Hz}$ 로 하였다. 발목 각도에 따른 각각 의 런지 운동을 수행하는 동안 운동의 시작과 끝 지점의 각 3 초를 제 외하고 27초간 측정된 신호를 분석하였다. 실험에서 측정하고자 하 는 근육의 근전도 신호량은 Root mean square (RMS) 값에 최대 수의 적 등척성 근수축 값(maximal voluntary isometric contraction, MVIC) 으로 나누어 백분율로 환산한 값으로 표준화하였다(\%MVIC). 전극 의 위치는 근육에서 가장 두꺼운 부분인 중간 지점과 이는 점에 부착 하였다. 각 근육의 전극 부착지점으로 넙다리곧은근은 무릎뼈 위가 쪽으로부터 $20 \mathrm{~cm}$ 위 지점, 안쪽넓은근은 무릎뼈 위안쪽 끝부분에서 $4 \mathrm{~cm}$ 위쪽 그리고 $3 \mathrm{~cm}$ 안쪽 지점, 가쪽넓은근은 넙다리뼈 수직선의 $15^{\circ}$ 가쪽, 무릎뼈의 위 모서리에서 위쪽으로 $10 \mathrm{~cm}$ 지점, 넙다리두갈 래근은 위앞엉덩뼈가시와 무릎뼈 위쪽모서리의 중간지점, 반힘줄근 은 넙다리두갈래근의 부착지점에서 안쪽으로 $3 \mathrm{~cm}$ 부분에 부착하였 다. ${ }^{15-18}$

\section{(3) 보조기 및 발판}

런지 운동 시 동일한 무릎관절의 각도를 제공할 뿐만 아니라 연구목 적에 따른 발목관절의 각도를 정량화하고 무릎 및 발목보조기를 착 

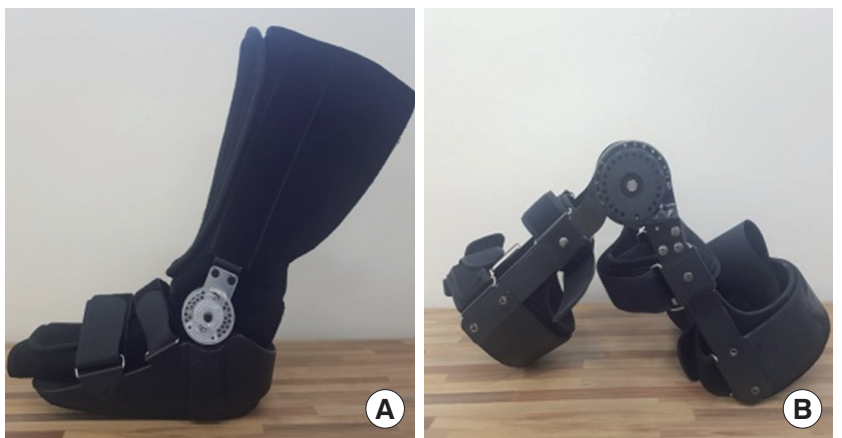

Figure 1. Knee and Ankle orthosis.

(A): Knee Orthosis (PCL knee-orthosis), (B): Ankle Orthosis (ROM Walker).

용한 상태에서 체중 지지를 동일하게 하기 위해 특수하게 제작된 발 판을 사용하였다. 무릎보조기를 사용하여 런지 운동시 최적의 근활 성도를 유도하기 위하여 무릎관절의 각도를 동일하게 $90^{\circ}$ 굽힘으로 설정하였다(Figure 1A). 또한, 발목보조기를 사용하여 런지 운동 시 발목관절의 각도를 실험설계에 따라 각각 중립, 발등굽힘 $20^{\circ}$, 발바닥 굽힘 $20^{\circ}$ 로 고정하였다(Figure 1B). 무릎 및 발목보조기는 연구 대상자 의 신체적 특성을 고려한 크기를 각각 적용하였으며, 런지 운동을 방 해하지 않으면서 불편감이 없도록 스트랩을 조절하여 최적화하였다.

마지막으로 안정된 지지면을 제공하기 위해 쐐기(wedge) 형태로 특 수 제작한 발판을 사용하여 발목관절 중립 시 런지 운동을 수행할 때와 같이 발등굽힘 $20^{\circ}$ 나 발바닥굽힘 $20^{\circ}$ 각도에서도 종아리의 수 직축이 지면과 수직을 이루도록 발아래에 위치하도록 하였다. 남성 용 발판의 크기는 빗변 $300 \mathrm{~mm}$, 높이 $102.61 \mathrm{~mm}$, 밑변 $281.91 \mathrm{~mm}$ 그리 고 너비 $120 \mathrm{~mm}$ 이며, 여성용 발판의 크기는 빗변 $280 \mathrm{~mm}$, 높이 95.77 $\mathrm{mm}$, 밑변 $263.11 \mathrm{~mm}$ 그리고 너비 $120 \mathrm{~mm}$ 로 설정하여 충분한 접촉 면 적을 동일하게 제공하도록 하였다.

\section{3. 실험절차}

본 연구는 단일 요인의 반복측정 실험 설계로 모든 대상자는 런지 운 동 시 세 가지 조건(중립, 발등굽힘 $20^{\circ}$, 발바닥굽힘 $20^{\circ}$ )을 무작위 순 서로 수행하였다. 선행연구에 따라 실험 중 나타날 수 있는 근 피로도 를 최소화하기 위하여 발목관절의 각도는 발목보조기의 다이얼 락 $0^{\circ}$ 를 기준으로 발등굽힘 $20^{\circ}$ 와 발바닥굽힘 $20^{\circ}$ 로 설정하였다..$^{19,20}$ 또 한 런지 운동 시 하지 근육의 가장 효과적인 근활성도를 유도하기 위 해 앞발과 뒷발의 간격을 실제 다리길이의 $40 \%$ 에 해당하는 길이로 동일하게 적용하였다. ${ }^{8}$

모든 대상자는 런지 운동을 수행하기 전 설정된 발목관절 각도와 동일한 무릎관절 $90^{\circ}$ 굽힘을 적용하기 위해 무릎보조기와 발목보조 기를 착용하였으며, 런지 운동 시 우세 다리가 앞으로 나가도록 하였 다. 런지 운동 및 근활성도 측정을 위한 우세 다리를 결정하기 위해
대상자들에게 굴린 공을 차도록 한 후 먼저 공을 차는 발을 우세 다 리로 결정하였다. 런지 운동을 수행하기 전 최대 수의적 등척성 수축 의 근활성도를 측정하기 위해 의자에 대상자를 앉힌 다음, 일반적으 로 무릎 폄 토크가 가장 큰 $60^{\circ}$ 무릎 굽힘으로 설정하여 종아리 먼쪽 부위에 굽힘방향으로 최대 저항을 주어 무릎관절 폄 운동을 하게 하 였다. ${ }^{21-23}$ 또한 무릎 굽힘의 최대 토크를 만들기 위해 무릎관절 완전 폄의 마지막 $20^{\circ}$ 굽힘으로 설정한 후 종아리 먼쪽 부위에 폄 방향으 로 최대 저항을 주어 무릎관절 굽힘 운동을 하게 하였다. ${ }^{24}$ 최대 수의 적 등척성 수축은 7 초 동안 측정하였으며 처음과 마지막 2 초를 제외 한 3 초 동안 측정된 근활성도를 분석에 사용하였다. 근 피로가 영향 을 주지 않도록 충분히 휴식을 취한 후 각각의 조건에 따른 런지 운 동을 무작위 순서로 3회씩 수행하였으며 이를 통해 수집된 근활성도 의 평균값을 분석에 사용하였다.

모든 측정은 동일한 연구자에 의해 측정되었으며, 측정하기 전 충 분히 숙련된 연구자에 의해 런지 운동에 대한 교육이 실시되었다. 런 지 운동 시 동일한 자세를 유지하도록 대상자는 몸통을 곧게 펴고 앞 쪽 다리의 무릎을 $90^{\circ}$ 굽히면서 뒤쪽 다리의 무릎이 땅에 닿을 것 같 은 느낌으로 내려가도록 하였다(Figure 2). 각각의 런지 운동 사이에 5 분간 휴식을 주어 반복 측정으로 인한 근 피로를 최소화하였다.

\section{4. 자료 분석}

본 연구에서 수집된 자료는 부호화한 후 Windows SPSS version 25.0 (IBM Co., USA) 프로그램을 이용하여 분석하였다. 연구 대상자의 일 반적인 특성인 연령, 신장, 몸무게 그리고 실제다리길이는 기술통계 를 실시하였고, 발목관절의 세 가지 각도 조건에서 런지 운동 시 하지 근육의 근활성도를 비교하기 위하여 정규성 검정(Shapiro-Wilk test) 에 따라 프리드만 검정(Friedman test)을 실시하였고 통계적 유의수준 은 $\mathrm{p}<0.05$ 로 설정하였다. 발목관절 각도 간의 근활성도 차이를 보기 위하여 윌콕슨 부호 순위 검증(Wilcoxon's signed-ranks test)을 실시하 였고 통계적 유의수준은 본페로니 보정(Bonferroni correction)을 이용 하여 $\mathrm{p}<0.017$ 로 설정하였다.

\section{결 과}

\section{1. 연구 대상자의 일반적 특성}

본 연구에 참가한 연구 대상자들은 총 20 명이며 성별 비는 남자 13 명, 여자 7명이었고, 평균 나이는 $23.4 \pm 1.8$ 세, 평균 키는 $169.9 \pm 8.1 \mathrm{~cm}$, 평 균 몸무게는 $70.3 \pm 14.0 \mathrm{~kg}$ 그리고 좌, 우 실제 다리길이의 평균은 86.1 $\pm 5.5 \mathrm{~cm}$ 이었다. 


\section{2. 세 가지 발목관절 각도에 따른 각 근육의 근활성도 비교}

발목관절 각도에 따른 각 근육의 근활성도를 비교한 결과 넙다리곧 은근, 가쪽넓은근, 반힘줄근 그리고 넙다리두갈래근에서 통계적으 로 유의한차이를 보였다 $(\mathrm{p}<0.05)$ (Table 1$)$.

각 근육별 발목관절 각도 사이의 비교 결과는 Figure 3 과 같다. 넙 다리곧은근의 근활성도는 중립, 발등굽힘 $20^{\circ}$, 발바닥굽힘 $20^{\circ}$ 순으 로 높았고, 중립일 때 근활성도는 발바닥굽힘 $20^{\circ}$ 일 때보다 유의하게 높았다 $(\mathrm{p}<0.017)$. 발등굽힘 $20^{\circ}$ 와 중립, 발등굽힘 $20^{\circ}$ 와 발바닥굽힘 $20^{\circ}$ 사이에서는 유의한 차이가 없었다 $(\mathrm{p}>0.017)$. 안쪽넓은근의 근활 성도는 중립, 발바닥굽힘 $20^{\circ}$, 발등굽힘 $20^{\circ}$ 순으로 높았고, 유의한 차 이가 없었다 $(\mathrm{p}>0.017)$. 가쪽넓은근의 근활성도는 중립, 발등굽힘 $20^{\circ}$, 발바닥굽힘 $20^{\circ}$ 순으로 높았고, 중립일 때 근활성도는 발등굽힘 $20^{\circ}$ 와 발바닥굽힘 $20^{\circ}$ 일 때보다 유의하게 높았다 $(\mathrm{p}<0.017)$. 발등굽힘 $20^{\circ}$ 와 발바닥굽힘 $20^{\circ}$ 사이에서는 유의한 차이가 없었다 $(\mathrm{p}>0.017)$. 반 힘줄근의 근활성도는 중립, 발바닥굽힘 $20^{\circ}$, 발등굽힘 $20^{\circ}$ 순으로 높 았고, 발등굽힘 $20^{\circ}$ 일 때 근활성도는 중립일 때보다 유의하게 낮았다 $(\mathrm{p}<0.017)$. 중립과 발바닥굽힘 $20^{\circ}$, 발등굽힘 $20^{\circ}$ 와 발바닥굽힘 $20^{\circ}$ 사
이에서는 유의한 차이가 없었다( $\mathrm{p}>0.017)$. 넙다리두갈래근의 근활성 도는 발바닥굽힘 $20^{\circ}$, 중립, 발등굽힘 $20^{\circ}$ 순으로 높았고, 발등굽힘

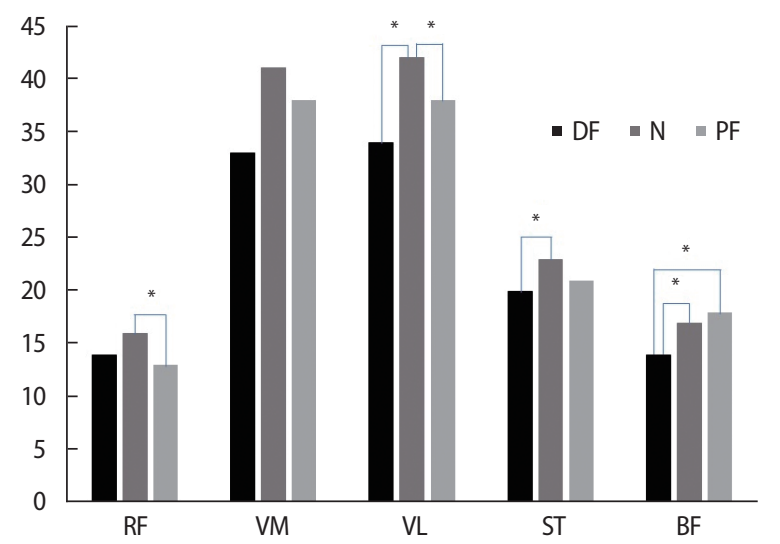

Figure 3. Comparison of EMG activity changes between the conditions as determined by Wilcoxon's signed-ranks test with Bonfferoni correction (Unit: \%MVIC). Mean \pm standard deviation, ${ }^{*} p<0.017$, DF: Dorsiflexion, N: Neutral, PF: Plantar flexion, RF: Rectus femoris, VM: Vastus medialis, VL: Vastus lateralis, ST: Semitendinosus, BF: Biceps femoris.
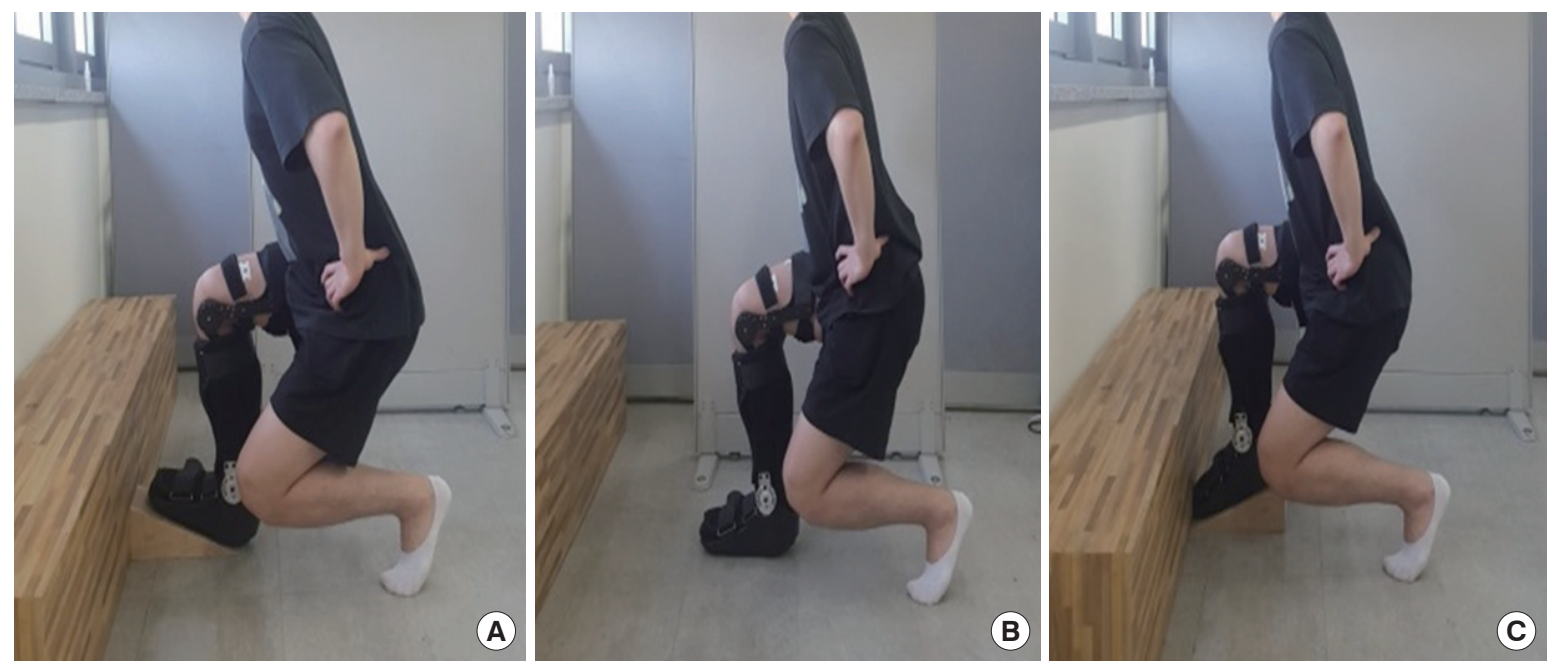

Figure 2. Lunge exercises according to their respective conditions.

(A): Lunge exercise at 20-degree dorsiflexion angle of ankle joint, (B): Lunge exercise at neutral angle of ankle joint, (C): Lunge exercise at 20-degree Plantarflexion angle of ankle joint.

Table 1. Comparison of EMG activity according to angle of ankle joint during lunge

(Unit: \%MVIC)

\begin{tabular}{lccccc}
\hline Muscle & $20^{\circ} \mathrm{DF}$ & $\mathrm{N}$ & $20^{\circ} \mathrm{PF}$ & $\chi^{2}$ & $\mathrm{p}$ \\
\hline RF & $14.58 \pm 7.91$ & $16.57 \pm 8.19$ & $13.64 \pm 7.57$ & 11.1 & $0.004^{*}$ \\
VM & $33.45 \pm 19.71$ & $40.94 \pm 21.58$ & $38.35 \pm 21.67$ & 5.7 & 0.058 \\
VL & $34.36 \pm 16.61$ & $42.82 \pm 17.89$ & $38.67 \pm 16.29$ & 16.3 & $<.001^{*}$ \\
ST & $20.98 \pm 18.60$ & $23.59 \pm 19.24$ & $21.40 \pm 16.08$ & 1 & $0.011^{*}$ \\
BF & $13.81 \pm 11.61$ & $17.35 \pm 11.92$ & $17.66 \pm 13.52$ & 12.9 & $0.002^{*}$ \\
\hline
\end{tabular}

Mean \pm standard deviation.

DF: Dorsiflexion, N: Neutral, PF: Plantar flexion, RF: Rectus femoris, VM: Vastus medialis, VL: Vastus lateralis, ST: Semitendinosus, BF: Biceps femoris. ${ }^{*} \mathrm{p}<0.05$. 
$20^{\circ}$ 일 때 근활성도는 중립과 발바닥굽힘 $20^{\circ}$ 일 때보다 유의하게 낮았 다( $\mathrm{p}>0.017)$. 중립과 발바닥굽힘 $20^{\circ}$ 사이에서는 유의한 차이가 없었 다( $\mathrm{p}>0.017)$.

\section{고 찰}

본 연구의 목적은 정상인을 대상으로 런지 운동 시 발목관절의 각도 변화에 따른 하지의 근활성도의 차이가 있는지를 알아보고자 실시 하였다. 본 연구결과 발등굽힘 $20^{\circ}$ 에서 런지 운동 시 가쪽넓은근, 반 힘줄근 그리고 넙다리두갈래근의 근활성도가 발목이 중립일 때 보 다 유의하게 낮았으며, 중립에서는 넓다리곧은근과 가쪽넒은근이 발바닥굽힘 $20^{\circ}$ 일 때보다 유의하게 근활성도가 높았다. 또한 발바닥 굽힘 $20^{\circ}$ 에서 런지 운동 시 넙다리두갈래근만이 발등굽힘 $20^{\circ}$ 보다 유의하게 근활성도가 높았다. 이는 런지 운동 시 발목관절의 각도에 따라 하지의 근활성도에 차이가 있어 근력강화 운동 시 이를 고려한 운동 설정이 필요할 것으로 사료된다.

발목관절에서 발등굽힘과 발바닥굽힘은 단일적인 움직임이 아니 라 돌림 움직임이 포함된 복합적인 움직임이다. 발등굽힘은 엎침(Pronation) 요소 중 하나이고 발등굽힘 시 발은 가쪽으로 돌림하며, 발바 닥굽힘은 뒤침(Supination) 요소로서 발이 안쪽으로 돌림한다.25,26 열 린사슬 운동과는 반대로 닫힌사슬 운동에서 발등굽힘은 정강뼈의 안쪽돌림을 동반하며, 발바닥굽힘 시에는 정강뼈의 가쪽돌림을 동 반한다. 발목의 이러한 복합적 움직임은 종아리의 회전과 관련되어 있고, 이는 무릎관절의 움직임에도 영향을 준다. 이와 같은 닫힌사슬 운동에서 발목관절의 각도 변화는 종아리의 움직임에 영향을 주고 이로 인한 무릎관절의 움직임은 넙다리 부위 근육의 수축에도 영향 을 준다. 선행연구에 따르면 닫힌사슬 운동에서 발목관절의 엎침은 종아리의 안쪽돌림을 야기하여 밖굽이 무릎을 증가시키며, 반대로 발목관절의 뒤침은 종아리의 가쪽돌림을 야기하여 안굽이 무릎을 증가시키고, 변화된 $\mathrm{Q}$ 각은 넙다리네갈래근의 수축에 변화를 일으 킨다.27-30 또한 변화된 $\mathrm{Q}$ 각은 뒤넙다리근의 모멘트 팔의 길이를 변화 시켜, 근활성도에 영향을 준다.31,32

본 연구 결과에서 런지 운동 시 발목관절의 발등굽힘 $20^{\circ}$ 가 발목 관절 중립에 비해 가쪽넓은근, 반힘줄근 그리고 넙다리두갈래근의 근활성도가 유의하게 낮았다. Antich와 Brewster ${ }^{33}$ 은 발목관절의 발 등굽힘은 굽힘 회피 반사와 관련되어 넙다리네갈래근의 수축이 감소 된다고 하였으며, 장딴지근의 수축을 야기하여 무릎관절을 약간 굽 힘시키므로 넙다리네갈래근 수축을 방해한다고 보고하였다. 또한 증 가된 장딴지근의 수축으로 인한 무릎관절의 굽힘에 대한 보상 작용 으로 상대적으로 낮은 뒤넙다리근의 근활성도가 나타난다. ${ }^{34}$ 또한 Lee 와 Park ${ }^{35}$ 연구에서는 발목관절의 각도에 따른 앉고 일어서기 동작 시
발등굽힘에서 역학적 부하량이 가장 낮았다고 보고하였으며, 이는 발등굽힘이 앞정강근의 근활성도를 증가시키고 이로 인한 대뇌피질 의 보조운동영역의 증가된 활성이 선행자세의 조정시간에 영향을 주 었기 때문에 동작의 부하량이 감소된다고 하였다. 따라서 본 연구에 서 발등굽힘 시 하지 근육의 근활성도가 전반적으로 낮은 것은 다른 조건에 비해 역학적 부하량이 상대적으로 낮았기 때문이라 사료된다. 또한, 본 연구에서 런지 운동 시 발목관절의 발바닥굽힘 20 도가 발 목관절 중립에 비해 넙다리곧은근과 가쪽넓은근의 근활성도가 유 의하게 낮았다. Signorile 등 36 의 연구에서 엉덩관절의 굽힘 $90^{\circ}$ 앉은 자세에서 무릎 $90^{\circ}, 150^{\circ}$ 그리고 $175^{\circ}$ 에서의 폄에 대한 등척성 수축을 할 때, 발의 중립 위치가 무릎관절 $90^{\circ}$ 와 $150^{\circ}$ 폄에서 가쪽돌림 위치 보다 가쪽넓은근의 근활성도가 높았다. Park 등 ${ }^{37}$ 은 등속성 운동에 서 발목관절의 과도한 발바닥굽힘은 무릎관절 폄근의 역학적 이점 을 감소시킨다고 하였으며, Yamada와 Demura ${ }^{38}$ 는 앉은 자세에서 발 목관절의 발바닥굽힘이 엉덩관절 굽힘 각도에 영향을 주며, Hwang 등 ${ }^{39}$ 은 의자 높이에 따른 발바닥굽힘 자세는 엉덩관절 굽힘 각도를 감소시키고 무릎관절 폄근의 굽힘 토크를 감소시킨다고 하였다. 따 라서 발목관절의 발바닥굽힘 위치에서 런지 운동은 무릎관절 폄근 의 역학적인 이득과 굽힘토크를 감소시켜 중립보다 낮은 근활성도를 보이는 것으로 사료된다.

본 연구에서 넙다리두갈래근은 발목관절의 발바닥굽힘 $20^{\circ}$ 에서 가장 높은 근활성도를 보였고, 발등굽힘 $20^{\circ}$ 와 유의한 차이를 보였지 만 중립과는 유의한 차이를 보이지 않았다. 또한 반힘줄근은 중립에 서 가장 높은 근활성도를 보였으며 발등굽힘 $20^{\circ}$ 와는 유의한 차이를 보였지만 발바닥굽힘 $20^{\circ}$ 와는 유의한차이를 보이지 않았다. 즉, 발목 관절의 발바닥굽힘 위치에서 런지 운동은 증가된 넙다리두갈래근의 근활성도와 감소된 반힘줄근의 근활성도 양상을 보였다. 운동형상 학적으로 정강뼈는 지면이 고정된 상태에서 무릎 굽힘 시 가쪽으로 돌림이 일어난다. Buford ${ }^{31}$ 의 연구에 따르면 정강뼈의 가쪽돌림 시에 넙다리두갈래근에서 가장 긴 모멘트팔을 보였으며 안쪽돌림 시에는 반힘줄근에서 긴 모멘트팔을 보였다. Jack 등 32 은 넙다리두갈래근과 반힘줄근의 모멘트팔에 따라 근활성도에 차이를 보인다고 하였다. 본 연구에서 런지 운동 시 발바닥굽힘은 정강뼈의 가쪽 돌림에 따라 넙다리두갈래근의 모멘트팔이 길어짐으로 내적토크가 증가되어 높 은 근활성도를 보인 반면, 반힘줄근의 모멘트팔은 짧아짐으로 내적 토크가 감소되어 낮은 근활성도를 보인 것으로 사료된다. 또한 발바 닥굽힘 시 장딴지근이 짧아짐으로 인해 무게중심이 상체에서는 앞 쪽으로 이동하고, 하체에서는 뒤쪽으로 이동하여 상대적으로 넙다 리두갈래근의 길이에 영향을 주고 이로 인한 넙다리두갈래근의 근 방추의 반사작용으로 높은 근활성도를 보인다고 할 수 있다.40,41

런지 운동은 닫힌사슬 운동에서 스쿼트와 함께 대표적인 하지 근 
력 강화 운동이며 특히, 스쿼트 동작보다 더 높은 좌우 균형조절능력 이 요구되고 안쪽넒은근과 가쪽넓은근의 근활성도 비를 높여 효과 적인 무릎 주변 근력의 균형을 유지할 수 있는 이점이 있다. $2,8,42$ 임상 적으로 런지 운동은 하지 근력 강화와 더불어 비외상성 무릎 넙다리 통증 증후군의 주 원인인 안쪽넒은근과 가쪽넓은근의 불균형적 근 활성도를 개선하고, 생리학적으로 근 약화가 먼저 일어나는 안쪽넒 은근의 선택적 강화에 특히 효과적이다. ${ }^{2}$ 또한, 런지는 양측 근력의 비대칭을 줄여 무릎관절 주위 연부조직 손상을 예방함으로써 임상 에서의 재활초기단계에서 많이 이용되고 있다. ${ }^{6}$ 본 연구 결과를 바탕 으로 임상적 관점에서 런지 운동 시 발목관절의 각도는 하지 근육의 근력강화에 있어 좀 더 효과적인 방법을 제시하고 있다. 본 연구에서 는 런지 운동 시 동일한 발목관절의 각도를 구현하기 위해 발목관절 의 발등굽힘 $20^{\circ}$ 및 발바닥굽힘 $20^{\circ}$ 를 고정하여 실시하였지만 실제 런지 운동 시 앞발을 앞으로 뻗는 길이에 따라 발목관절의 각도는 다 양하게 변화될 수 있다. 즉 앞발을 과도하게 뻗은 경우에는 발목관절 의 발바닥굽힘 된 상태가 될 것이며, 앞발을 부족하게 뻗은 경우에는 발목관절의 발등굽힘 된 상태가 될 것이다. 따라서 본 연구는 하지 근 육의 근력강화를 위해 런지 운동 시 앞발을 뻗는 최적의 길이를 찾기 보다는 적절한 발목관절의 각도를 찾는 것에 주요한 관점을 두었다. 본 연구 결과를 근거로 런지 운동 시 앞발을 뻗는 길이에 관계없이 발 목관절의 발등굽힘과 발바닥굽힘이 발생되는 것을 최대한 피하고, 중립 위치로 수행하는 것이 전반적인 하지 근육의 근활성도 증가에 효과적이라고 볼수 있다.

본 연구의 제한점으로는 젊은 20 대 성인을 대상으로만 연구하여 일반화하였으므로, 다양한 연령과 환자들을 대상으로 적용하기에 제한이 있고, 발목관절 각도에 따른 엉덩관절의 각도 변화와 몸통의 움직임을 고려하지 않았다. 또한 중재적 관점에서 발목관절 각도로 인한 런지 운동의 지속적인 효과를 파악할 수 없었다. 향후 연구에서 는 다양한 연령과 환자들을 대상으로 발목관절 각도에 따른 지속적 인 런지 운동으로 인한 중재적 효과를 파악하고 하지와 몸통의 운동 형상학적 특성을 고려한 효과적인 런지 운동을 제시할 필요가 있다.

\section{REFERENCES}

1. Yeo SJ. Analysis of lower-limb muscle by leg limb exercise for men in their 20s: kettle bell swing, squat, lunge. Kyungpook national university. Dissertation of Mater's Degree. 2015.

2. Ekstrom RA, Donatelli RA, Carp KC. Electromyographic analysis of core trunk, hip, and thigh muscles during 9 rehabilitation exercises. J Orthop Sports Phys Ther. 2007;37(12):754-62.

3. Escamilla R, Zheng N, Macleod T et al. Patellofemoral joint force and stress during the wall squat and one-leg squat. Med Sci Sports Exerc. 2009;41(4):879.
4. Park MH, Song JK, Kim JG. Effect of 12-week resistance exercise on patellofemoral pain syndrome in young female aged 20 40 years. Korean J Phys Educ. 2007;46(4):417-26.

5. Earl J, Schmitz RJ, Arnold B. Activation of the VMO and VL during dynamic mini-squat exercises with and without isometric hip adduction. J Electromyogr Kinesiol. 2001;11(6):381-6.

6. Westfall DC, Worrell TW. Anterior knee pain syndrome: role of the vastus medialis oblique. J Sport Rehabil. 1992;1(4):317-25.

7. Ahn SH, Lee SK, Lee KJ et al. The comparison of muscle activities in the right leg during squatting according to various ankle angles. PNF \& Mov. 2017;15(3):259-66.

8. Park HY, Kim NH, Cha YJ. Comparison of muscle activity in proximal muscle of lower extremities during lunge according to the anterior-posterior distance of foot position. J Korean Soc Phys Med. 2018;13(4):1318.

9. Park SR, Lee MG, Choi SM. Comparison of electromyographic activity of quadriceps during Lunge according to ankle positions in ssireum players with patellofemoral pain syndrome. Exerc Sci. 2010;19(3):21930.

10. Kim SJ. Effects of lunge excersice with instability on lower limb activity. Daegu Catholic University. Dissertation of Master's Degree. 2018.

11. Anderson K, Behm DG. Trunk muscle activity increases with unstable squat movements. Can J Appl Physiol. 2005;30(1):33-45.

12. Oh TY. The effects of squatting exercise with gym ball and wall on lower extremity muscles activation. J Korean Soc Phys Med. 2013;8(4):647-53.

13. Richards J, Thewlis D, Selfe J et al. A biomechanical investigation of a single-limb squat: implications for lower extremity rehabilitation exercise. J Athl Train. 2008;43(5):477-82.

14. Magee DJ. Orthopedic physical. 6th ed. Seoul, Elsevier Korea LLC, 2014: 808.

15. Cowan SM, Bennell KL, Hodges PW et al. Delayed onset of electromyographic activity of vastus medialis obliquus relative to vastus lateralis in subjects with patellofemoral pain syndrome. Arch Phys Med Rehabil. 2001;82(2):183-9.

16. Gilleard W, McConnell J, Parsons D. The effect of patellar taping on the onset of vastus medialis obliquus and vastus lateralis muscle activity in persons with patellofemoral pain. Phys Ther. 1998;78(1):25-32.

17. McHugh MP, Connolly DA, Eston RG et al. Electromyographic analysis of exercise resulting in symptoms of muscle damage. J Sports Sci. 2000; 18(3):163-72.

18. Winter DA, Yack H. EMG profiles during normal human walking: stride-to-stride and inter-subject variability. Clin Neurophysiol. 1987; 67(5):402-11.

19. Mademli L, Arampatzis A, Morey-Klapsing G et al. Effect of ankle joint position and electrode placement on the estimation of the antagonistic moment during maximal plantarflexion. J Eletromyogr Kines. 2004;14(5): 591-7.

20. Morse CI, Thom JM, Reeves ND et al. In vivo physiological cross-sectional area and specific force are reduced in the gastrocnemius of elderly men. J Appl Physiol. 2005;99(3):1050-5.

21. Clarkson HM. Musculoskeletal assessment: joint range of motion and manual muscle strength. Philadelphia, Lippincott Williams \& Wilkins, 2004:328-9.

22. Kubo K, Ohgo K, Takeishi R et al. Effects of series elasticity on the hu- 
man knee extension torque-angle relationship in vivo. Res Q Exercise Sport. 2006;77(4):408-16.

23. Kulig K, Andrews JG, Hay JG. Human strength curves. Exerc Sport Sci Rev. 1984;12(1):417-66.

24. Smidt GL. Biomechanical analysis of knee flexion and extension. J Biomech. 1973;6(1):79-92.

25. Neumann DA. Kinesiology of the Musculoskeletal System. 2nd ed. Seoul, Bub Mun Publishing Company, 2011;597.

26. Stiehl JB. Inman's joints of the ankle. Philadelphia, Williams \& Wilkins, 1991:278-94.

27. Blake R, Burns D, Colson J. Etiology of atraumatic medial knee pain. J Am Podiatr Med Assoc. 1981;71(10):580-3.

28. Greenfield B. Evaluation of overuse syndrome. In: Donatelli R, ed, Biomechanics of the Foot and Ankle, Piladelphia, Davis Company, 1990: 201-3.

29. Olerud C, Berg P. The variation of the $Q$ angle with different positions of the foot. Clin Orthop Relat Res. 1984(191):162-5.

30. Schamberger W. The malalignment syndrome in runners. Phys Med Rehabil Clin N Am. 2016;27(1):237-317.

31. Buford Jr WL, Ivey Jr FM, Nakamura T et al. Internal/external rotation moment arms of muscles at the knee: Moment arms for the normal knee and the ACL-deficient knee. Knee. 2001;8(4):293-303.

32. Lunnen JD, Yack J, LeVeau BF. Relationship between muscle length, muscle activity, and torque of the hamstring muscles. Phys Ther. 1981; 61(2):190-5.

33. Antich T, Brewster CE. Modification of quadriceps femoris muscle exercises during knee rehabilitation. Phys Ther. 1986;66(8):1246-50.

34. Morgan KD, Donnelly CJ, Reinbolt JA. Elevated gastrocnemius forces compensate for decreased hamstrings forces during the weight-acceptance phase of single-leg jump landing: Implications for anterior cruciate ligament injury risk. J Biomech. 2014;47(13):3295-302.

35. Lee MM, Park DS. A comparison of muscle activation and mechanical loading according to the degree of ankle joint motion during a sit-tostand task. J Korean Soc Phys Med. 2017;12(4):113-22.

36. Signorile JF, Kacsik D, Perry A et al. The effect of knee and foot position on the electromyographical activity of the superficial quadriceps. J Orthop Sports Phys Ther. 1995;22(1):2-9.

37. Park SY, Kim CS, Kim JH et al. Assessment of isokinetic muscle strength in the knee extensor through the ankle joint angles. J Kor Phys Ther. 2011; 23(1):13-9.

38. Yamada T, Demura SI. Influence of the relative difference in chair seat height according to different lower thigh length on floor reaction force and lower-limb strength during sit-to-stand movement. J Physiol Anthropol Appl Hum Sci. 2004;23(6):197-203.

39. Hwang SJ, Son JS, Kim JY et al. Analysis of joint movements and muscle length during sit-to-stand at various sitting heights in the korean elderly daily life. World Congress on Medical Physics and Biomedical Engineering. 2009:25:17-9.

40. Lehmkuhl LD, Smith LK. Brunnstrom's clinical kinesiology. 6th ed. Philadelphia, Davis Co, 2012:453-5.

41. Snow RE, Williams KR. High heeled shoes: their effect on center of mass position, posture, three-dimensional kinematics, rearfoot motion, and ground reaction forces. Arch Phys Med Rehabil. 1994;75(5):568.

42. Fulkerson JP. Diagnosis and treatment of patients with patellofemoral pain. Am J Sports Med. 2002;30(3):447-56. 